\title{
PPIA Gene
}

National Cancer Institute

\section{Source}

National Cancer Institute. PPIA Gene. NCI Thesaurus. Code C156927.

This gene plays a role in protein folding, cyclosporin binding and HIV virion assembly. 